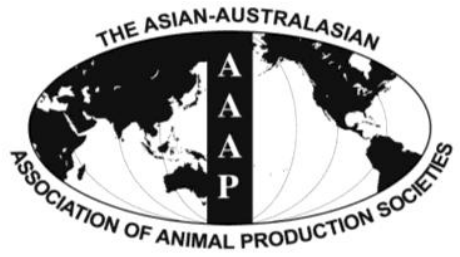

Asian-Aust. J. Anim. Sci.

Vol. 26, No. 4 : 537-544 April 2013

http://dx.doi.org/10.5713/ajas.2012.12463

www.ajas.info

pISSN 1011-2367 elSSN 1976-5517

\title{
Effects of Enzyme Treated Palm Kernel Expeller on Metabolizable Energy, Growth Performance, Villus Height and Digesta Viscosity in Broiler Chickens
}

\author{
P. Saenphoom ${ }^{1}$, J. B. Liang ${ }^{2, *}$, Y. W. Ho ${ }^{1}$, T. C. Loh $^{3}$ and M. Rosfarizan ${ }^{4}$ \\ ${ }^{1}$ Laboratory of Industrial Biotechnology, Institute of Bioscience, Malaysia
}

\begin{abstract}
This study examined whether pre-treating palm kernel expeller (PKE) with exogenous enzyme would degrade its fiber content; thus improving its metabolizable energy (ME), growth performance, villus height and digesta viscosity in broiler chickens fed diets containing PKE. Our results showed that enzyme treatment decreased $(\mathrm{p}<0.05)$ hemicellulose and cellulose contents of PKE by 26.26 and $32.62 \%$, respectively; and improved true ME (TME) and its nitrogen corrected value $\left(\mathrm{TME}_{\mathrm{n}}\right.$ ) by $38 \%$ and $33 \%$, respectively, compared to the raw sample. Average daily gain (ADG), feed intake and feed conversion ratio (FCR) of chickens fed on different dietary treatments in the grower period were not significantly different. Although there was no difference in feed intake ( $p>0.05)$ among treatment groups in the finisher period, ADG of chickens in the control (PKE-free diet) was higher $(\mathrm{p}<0.05)$ than in all treatment groups fed either 20 or 30\% PKE, irrespective of with or without enzyme treatment. However, ADG of birds fed with $20 \%$ PKE was higher than those fed with 30\% PKE. The FCR of chickens in the control was the lowest (2.20) but not significantly different from those fed $20 \%$ PKE diets while birds in the 30\% PKE diets recorded higher ( $p>0.05$ ) FCR. The intestinal villus height and crypt depth (duodenum, jejunum and ileum) were not different ( $p>0.05$ ) among treatments except for duodenal crypt depth. The villus height and crypt depth of birds in enzyme treated PKE diets were higher $(\mathrm{p}<0.05)$ than those in the raw PKE groups. Viscosity of the intestinal digesta was not different ( $p>0.05)$ among treatments. Results of this study suggest that exogenous enzyme is effective in hydrolyzing the fiber (hemicellulose and cellulose) component and improved the ME values of PKE, however, the above positive effects were not reflected in the growth performance in broiler chickens fed the enzyme treated PKE compared to those received raw PKE. The results suggest that PKE can be included up to $5 \%$ in the grower diet and $20 \%$ in the finisher diet without any significant negative effect on FCR in broiler chickens. (Key Words: Palm Kernel Expeller, True Metabolizable Energy, Enzyme, Broiler)
\end{abstract}

\section{INTRODUCTION}

The primary challenge of using agro-byproducts as feed ingredients for mono-gastric animals, such as poultry, is to release the nutrients bond to the fiber component of these materials. Palm kernel expeller (PKE), a byproduct of the palm oil industry, contains 13 to 20\% fiber (Alimon, 2004) with 58 to $78 \%$ of the fiber is insoluble glucomannan (Daud

\footnotetext{
* Corresponding Author: J. B. Liang. Tel: +60-3-8947-2132, Fax: +60-3-8947-2213, E-mail: jbliang@ @utra.upm.edu.my

2 Laboratory of Animal Production, Institute of Tropical Agriculture, Malaysia.

3 Department of Animal Science, Faculty of Agriculture, Malaysia.

4 Department of Bioprocess Technology, Faculty of Biotechnology and Biomolecular Sciences, Universiti Putra Malaysia, 43400 UPM Serdang, Malaysia.

Submitted Aug. 31, 2012; Accepted Oct. 31, 2012; Revised Dec. 2, 2012
}

and Jarvis, 1992; Dusterhoft et al., 1992; Sundu and Dingle, 2003) thus making it resembles very much cellulose by being crystalline, hard and water insoluble (Knudsen, 1997; Sundu et al., 2006).

Supplementing exogenous enzymes into broiler diets containing PKE to enhance intake and growth performance has been previously reported (Yahya et al., 2000; Iyayi and Davies, 2005; Omojola and Adesehinwa, 2007; Sekoni et al., 2008) but results from the above studies were inconsistent, presumably due to different enzymes were used among studies and/or other influencing factors within the gastrointestinal tract (GIT) of the birds which may affect the activity of the supplemented enzymes. The latter includes i) differences in rate of passage resulting in variable retention times for the enzyme to act on the PKE in the GIT and ii) the core body temperature of chickens $\left(41^{\circ} \mathrm{C}\right)$ (Tessier et al., 2003) is below the optimal temperature for enzymes activity (50 to $60^{\circ} \mathrm{C}$ ) (Pardo and Forchiassin, 1999; Siti Norita et al., 
2010) and thus reducing their efficacy.

Saenphoom et al. (2011) recently reported that pretreating PKE with exogenous enzyme degraded its cellulose and hemicelluloses components by 22.14 and $35.70 \%$, respectively, and releasing multi-folds more reducing sugars than the raw PKE. The above data suggested large proportion of the indigestible polysaccharides in the PKE was hydrolyzed into soluble sugars, which now can be used by mono-gastric animals such as poultry. However, whether the reduced fiber content and the released nutrients based on chemical analysis can be absorbed and metabolized by the animals need to be tested. In this study, we examined whether pre-treating PKE with exogenous enzyme can improve its metabolizable energy value and growth performance, villus height and digesta viscosity of broiler chickens fed diets containing the enzyme treated PKE.

\section{MATERIALS AND METHODS}

\section{Preparation of PKE samples}

Raw PKE was obtained from a commercial kernel oil extraction mill in Klang, Selangor, Malaysia and ground to uniform size of about $2.5 \mathrm{~mm}$ before undergoing enzymatic treatment. The enzyme used for this study consisted mainly cellulase and mannanase. Approximately $500 \mathrm{~g}$ of PKE was placed in $2 \mathrm{~L}$ laboratory beaker in which water was added to achieve a moisture content of about $80 \%$ before adding the enzyme at $0.67 \%$ of the weight of PKE (Saenphoom et al., 2011). The PKE sample was incubated at $55^{\circ} \mathrm{C}$ in water bath for $18 \mathrm{~h}$ after which the samples were dried for $48 \mathrm{~h}$ at $60^{\circ} \mathrm{C}$ and stored at $4^{\circ} \mathrm{C}$ for later use. The above procedure was repeated until sufficient amount of enzyme treated PKE was obtained for the study.

\section{True metabolizable energy (TME) assay}

The TME bioassay was conducted according to the procedure of Sibbald (1975) modified by McNab and Blair (1988) and the experimental protocol of Sibbald (1989) was used for the measurement of endogenous energy losses (EEL). Thirty six (36) birds (Cobb 500) of $60 \mathrm{~d}$ old (approximately $2.9 \mathrm{~kg}$ ), raised with commercial starter (CP $21.4 \%$ ), grower (CP 18.7\%) and finisher (17.0\%) diets kept in individual metabolic cages were used for this study. Three feed ingredients consisted of corn (as reference), raw PKE and enzyme treated PKE (as previously described) were tested. Each of the above test ingredients was randomly assigned to a group of 9 birds with another group of 9 birds used for the estimation of endogenous nitrogen and energy losses (Bilgili et al., 1982).

Forty-eight hours prior to feeding the test ingredients, feed was withdrawn from all birds. During fasting, birds were fed with $100 \mathrm{ml}$ glucose solution $(600 \mathrm{~g} / \mathrm{L})$ at two equal doses of $50 \mathrm{ml}$ to meet maintenance energy requirement of the birds. The birds were fed $15 \mathrm{~g}$ of test ingredient using a stainless steel funnel and the fourth group continued to fast. Total excreta voided were collected at 24 $\mathrm{h}$ and $48 \mathrm{~h}$ after feeding, weighed, dried at $60^{\circ} \mathrm{C}$ and ground. Chemical compositions the test ingredients and excreta samples were determined.

\section{Feeding trial}

Treatment diets were formulated to meet nutrient requirements of poultry according to the NRC (1994). In the growth performance trial, all birds were fed with commercial starter feed for the first 11 days. A combination of three grower diets (0\% raw PKE, 5\% raw PKE and 5\% enzyme treated PKE) and five finisher diets (0\% raw PKE, $20 \%$ raw PKE, $20 \%$ enzyme treated PKE, 30\% raw PKE and $30 \%$ enzyme treated PKE) giving a total of 9 dietary combinations were used as treatment diets in this study. The compositions of the dietary treatments are shown in Table 1.

Two hundred and twenty five (225) male day-old chicks (Cobb 500) purchased from a commercial breeder farm in Selangor, Malaysia were randomly allocated into the above mentioned nine treatment groups. Each treatment consisted of five replications and five birds per replicate (5 birds/cages) making up a total of 25 birds per treatment. The birds were reared from d 1 to 11 (11 days) using starter, d 12 to 21 (10 days) grower and d 22 to 41 (20 days) finisher feed in battery cages. All birds were vaccinated against Newcastle disease (ND) and Infectious Bursal disease (IBD) on d 7 and 14, respectively. Feed and clean drinking water were offered ad libitum to the birds. Feed intake (FI) was recorded daily and body weights (BW) weekly for estimations of the average daily gain (ADG) and feed conversion ratio (FCR) during the various growth periods.

At the end of the trial period, ten birds from each treatment were randomly sampled and slaughtered. Duodenum, jejunum and ileum of the small intestine were sampled for histological examination. Villus height and crypt depth were measured according to the method described by Bejo (1990). Digesta samples were collected from the ileum to determine their viscosity. Four digesta samples from each treatment combination were used to estimate digesta viscosity using the Rheometer system with $0.5 \mathrm{ml}$ of each sample in the Rheometer (Model: HAAKE MARS, Modular advanced Rheometer system, Germany) for $10 \mathrm{~min}$ at $25^{\circ} \mathrm{C}$. Digesta viscosity was presented in Pascal-seconds (Pa.s).

\section{Proximate analysis}

Samples of the diets, raw PKE, enzyme treated PKE and feces were analyzed for dry matter (DM), crude protein (CP), ash, ether extract (EE) (AOAC, 1990), neutral detergent fiber (NDF), acid detergent fiber (ADF) and acid 
Table 1. Compositions of the dietary treatments

\begin{tabular}{|c|c|c|c|c|c|}
\hline \multirow[b]{2}{*}{ Ingredients (\%) } & \multicolumn{2}{|c|}{ Grower diets } & \multicolumn{3}{|c|}{ Finisher diets } \\
\hline & $0 \%$ raw PKE & $\begin{array}{c}\text { 5\% raw PKE and } \\
5 \% \text { enzyme treated } \\
\text { PKE }\end{array}$ & $0 \%$ raw $\mathrm{PKE}$ & $\begin{array}{c}20 \% \text { raw PKE and } \\
20 \% \text { enzyme treated } \\
\text { PKE }\end{array}$ & $\begin{array}{c}30 \% \text { raw PKE and } \\
30 \% \text { enzyme treated } \\
\text { PKE }\end{array}$ \\
\hline$\overline{\text { Corn }}$ & 61.87 & 56.36 & 63.30 & 48.65 & 39.99 \\
\hline Soybean meal & 30.13 & 29.16 & 22.46 & 18.79 & 16.88 \\
\hline Wheat bran & 0 & 0 & 7.56 & 2.50 & 1.00 \\
\hline PKE & 0 & 5.00 & 0 & 20.00 & 30.00 \\
\hline Palm oil & 3.90 & 5.44 & 3.00 & 6.55 & 8.73 \\
\hline $\mathrm{CaCO}_{3}$ & 1.25 & 1.23 & 1.18 & 1.08 & 1.03 \\
\hline Dicalcium phosphate & 1.80 & 1.79 & 1.45 & 1.46 & 1.45 \\
\hline Common salt & 0.41 & 0.36 & 0.37 & 0.19 & 0.10 \\
\hline Vitamin premix $^{1}$ & 0.06 & 0.06 & 0.06 & 0.06 & 0.06 \\
\hline Mineral premix ${ }^{2}$ & 0.10 & 0.10 & 0.10 & 0.10 & 0.10 \\
\hline DL-methionine & 0.24 & 0.24 & 0.22 & 0.25 & 0.26 \\
\hline L-lysine $\mathrm{HCl}$ & 0.17 & 0.19 & 0.23 & 0.30 & 0.33 \\
\hline Choline & 0.06 & 0.06 & 0.06 & 0.06 & 0.06 \\
\hline Antioxidant & 0.01 & 0.01 & 0.01 & 0.01 & 0.01 \\
\hline Total & 100 & 100 & 100 & 100 & 100 \\
\hline \multicolumn{6}{|l|}{ Calculated analyses } \\
\hline ME (Mcal/kg) & 3.08 & 3.08 & 2.99 & 2.99 & 2.99 \\
\hline $\mathrm{CP}(\%)$ & 19.00 & 19.00 & 16.92 & 16.92 & 16.92 \\
\hline $\mathrm{Ca}(\%)$ & 0.96 & 0.96 & 0.85 & 0.85 & 0.85 \\
\hline Available P (\%) & 0.48 & 0.48 & 0.42 & 0.42 & 0.42 \\
\hline $\mathrm{Na}(\%)$ & 0.19 & 0.19 & 0.18 & 0.18 & 0.18 \\
\hline Lysine (\%) & 1.10 & 1.10 & 0.99 & 0.99 & 0.99 \\
\hline Methionine (\%) & 0.53 & 0.54 & 0.49 & 0.52 & 0.52 \\
\hline Methionine+cystein $(\%)$ & 0.84 & 0.84 & 0.77 & 0.77 & 0.77 \\
\hline
\end{tabular}

${ }^{1}$ Vitamin premix supplied per ton of diet: vitamin A, $50.000 \mathrm{MIU}$; vitamin $\mathrm{D}_{3}, 10.000 \mathrm{MIU}$; vitamin $\mathrm{E}, 75.000$; vitamin $\mathrm{K}_{3}, 20.000 \mathrm{~g}$; vitamin $\mathrm{B}_{1}, 10.000$ $\mathrm{g}$; vitamin $\mathrm{B}_{2}, 30.000 \mathrm{~g}$; vitamin $\mathrm{B}_{6}, 20.000 \mathrm{~g}$; vitamin $\mathrm{B}_{12}, 0.100 \mathrm{~g}$; calcium D-pantothenate, $60.000 \mathrm{~g}$; nicotinic acid, $200.000 \mathrm{~g}$; folic acid, $5.000 \mathrm{~g}$; biotin, $235.000 \mathrm{mg}$.

${ }^{2}$ Mineral premix supplied per ton of diet: Se, 0.20 g; Fe, 80 g; Mg, 100 g; Zn, 80 g; Cu, 15 g; KCl, 4 g; MgO, 0.60 g; $\mathrm{NaHCO}_{3}$.

detergent lignin (ADL) (Goering and Van Soest, 1970). Hemicellulose was calculated as NDF-ADF while cellulose as ADF-ADL. Gross energy was determined using bomb calorimeter (C2000 Basic, IKA@Werke, Germany).

\section{Statistic analyses}

The experimental data were subjected to analysis of variance procedures of SAS software (SAS, 1998). Differences among treatment means in TME were tested using t-test (independent group) (Steel and Torrie, 1980). Differences among combination treatment means in the feeding trial were tested using Duncan's New Multiple Range Test (DMRT) and orthogonal contrast for specific comparison. Orthogonal contrasts were performed when compared with control (raw PKE), types and levels of PKE. A significance level of $p<0.05$ was used to differentiate between means.

\section{RESULTS AND DISCUSSION}

\section{Chemical composition of PKE}

Chemical compositions of enzyme treated and raw PKE are shown in Table 2. Crude protein content of the enzyme treated PKE (20.84\%) was 3-percent unit higher than the raw PKE (17.85\%). Enzyme treatment decreased NDF and ADF contents by 18.59 and $12.92 \%$ ( $\mathrm{p}<0.05)$, respectively, resulting in hemicellulose content to decrease from 33.78 to $24.91 \%$ and cellulose content from 32.80 to $22.10 \%$. The exogenous enzyme used in this study thus effectively

Table 2. Chemical compositions and gross energy of PKE with and without enzyme treatments (values as \% of DM)

\begin{tabular}{|c|c|c|c|}
\hline \multirow[b]{2}{*}{ Item } & \multicolumn{2}{|c|}{ Treatment } & \multirow[b]{2}{*}{ SEM } \\
\hline & Raw PKE & $\begin{array}{c}\text { Enzyme } \\
\text { treated PKE }\end{array}$ & \\
\hline Crude protein $(\%)$ & $17.85^{b}$ & $20.84^{a}$ & 0.37 \\
\hline Ether extract $(\%)$ & 7.41 & 7.28 & 0.83 \\
\hline $\operatorname{Ash}(\%)$ & 5.24 & 5.51 & 0.90 \\
\hline $\operatorname{NDF}(\%)$ & $79.28^{a}$ & $64.54^{\mathrm{b}}$ & 1.82 \\
\hline $\operatorname{ADF}(\%)$ & $45.51^{a}$ & $39.63^{b}$ & 0.98 \\
\hline $\operatorname{ADL}(\%)$ & 12.70 & 17.53 & 1.66 \\
\hline Gross energy $(\mathrm{MJ} / \mathrm{kg})$ & 20.35 & 20.52 & 0.36 \\
\hline
\end{tabular}

a,b Values within the same row with different superscripts differed significantly $(\mathrm{p}<0.05)$. 


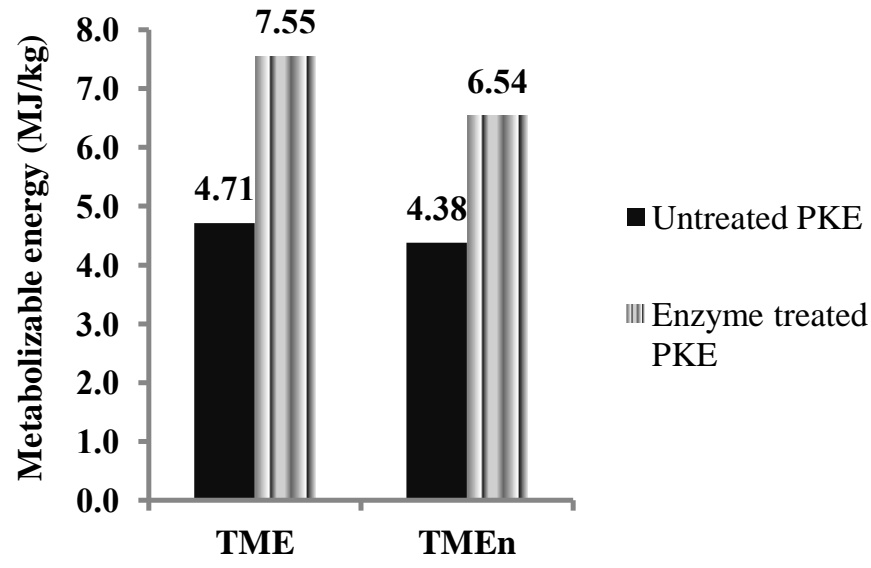

Figure 1. True metabolizable energy (TME) and nitrogen corrected TME $\left(\mathrm{TME}_{\mathrm{n}}\right)$ of raw and enzyme treated PKE.

hydrolyzed complex hemicellulose and cellulose and reduced their contents by $26.26 \%$ and $32.62 \%$, respectively, compared to the raw PKE. The above results reaffirmed our previous study (Saenphoom et al., 2011) which reported that pre-treating PKE with exogenous enzyme reduced hemicellulose and celluloses components by 26.26 and $32.62 \%$, respectively. The significant reduction in hemicellulose content indicating the enzyme is effective in breaking down mannan-hemicellulose, the main component of the fiber in PKE (Daud and Jarvis, 1992; Yokomizo, 2004).

\section{True metabolizable energy (TME) and nitrogen corrected TME (TME $)$}

Enzyme treatment increased $(\mathrm{p}<0.05)$ TME value of PKE by $60.3 \%$ (from 4.71 to $7.55 \mathrm{MJ} / \mathrm{kg}$ ) and $\mathrm{TME}_{\mathrm{n}}$ value by $49.3 \%$ (from 4.38 to $6.54 \mathrm{MJ} / \mathrm{kg}$ ) (Figure 1). The above improvements were in agreement with the reduction of the fiber (cellulose and hemicelluloses) in the enzyme treated PKE compared to the raw PKE (Table 1). The above TME values were near to those previously reported in Malaysia (7.36 to $7.61 \mathrm{MJ}$ TME/kg) by Yeong et al. (1983) and Chong et al. (1998), but lower than that reported (12.37 MJ $\mathrm{TME} / \mathrm{kg}$ ) by Muangkeow and Chinajariyawong (2009) in Thailand. Corn was used as the reference ingredient in this study, which was estimated to be $14.51 \mathrm{MJ} \mathrm{TME} / \mathrm{kg}$, approximately $5 \%$ lower than the value $(15.36 \mathrm{MJ} / \mathrm{kg})$ reported by Nadeem et al. (2005) and thus the TME values obtained in our study are reliable. The TME value of PKE (a high fiber agro-biomass) reported by Muangleow and Chinajariyawong (2009) seems to be unrealistically high taking into consideration that TME value of corn was estimated to range from only 14.51 (present study) to 15.36 (Nadeem et al., 2005).

\section{Feeding trial}

In the grower period (d 12 to 21 ), ADG, FI and FCR of chickens fed PKE free diet and those fed 5\% PKE (enzyme treated or raw PKE) were not significantly $(\mathrm{p}>0.05)$ different (Table 2). The above results suggest that PKE can be included up to $5 \%$ in broiler-grower diet without any significant effect on ADG and FCR, averaged $50.51 \mathrm{~g} / \mathrm{bird}$ and 1.55 , respectively.

Although there was no difference in FI ( $p>0.05)$ among treatment groups in the finisher period (d 22 to 41), ADG of chickens in the PKE-free control (70.49 g/d) was significantly higher $(\mathrm{p}<0.05)$ than all treatments fed either 20 or $30 \%$ PKE, irrespective of with or without enzyme treatment. In general, feeding of PKE (enzyme treated or raw PKE) during the grower period did not affect subsequent $\mathrm{ADG}$ of chickens during the finisher period. However, ADG of birds fed with 30\% PKE (T3, T5, T7 and T9) was lower than those fed with $20 \%$ PKE (T2, T4, T6 and T8) (55.16 vs $64.00 \mathrm{~g} / \mathrm{d})$. The FCR of chickens in the control PKE-free diet was the lowest (2.20) but was not significantly different from those fed $20 \%$ PKE diets (T2, T4, T6 and T8) while birds in the 30\% PKE diets recorded higher ( $p>0.05)$ FCR (Table 2). The above results thus suggested that to prevent any negative effect on ADG and FCR, the maximum inclusion rate of PKE (enzyme treated or raw PKE) is $20 \%$ in finisher broiler diet.

As for the overall feeding trial, FI and ADG of chickens in the PKE-free control diet were higher $(p<0.05)$ than the respective values containing PKE (irrespective of inclusion levels or enzyme treatments). Just as those in the finisher period, ADG of chickens fed 20\% PKE diets (averaged $59.28 \mathrm{~g} / \mathrm{d})$ were higher $(\mathrm{p}<0.05)$ than those in the $30 \%$ PKE diets $(53.44 \mathrm{~g} / \mathrm{d})$. FCR of chickens in treatment 1 (PKE free; 2.02) were not significantly different with those fed $20 \%$ PKE (T2, T4, T6 and T8) but lower $(\mathrm{p}<0.05)$ that those in the 30\% PKE diets (T3, T5, T7 and T9). In general, enzyme treatment did not improve ADG or FCR of chickens fed the enzyme treated PKE (Table 3).

Majority of the previous research which aimed at 
Table 3. Growth performance of chicken fed with different dietary combination treatments

\begin{tabular}{|c|c|c|c|c|c|c|c|c|c|c|}
\hline Parameters & $\mathrm{T} 1$ & $\mathrm{~T} 2$ & $\mathrm{~T} 3$ & $\mathrm{~T} 4$ & T5 & T6 & $\mathrm{T} 7$ & $\mathrm{~T} 8$ & T9 & SEM \\
\hline \multicolumn{11}{|l|}{ Grower (10 days) } \\
\hline $\mathrm{ADG}$ (g/bird) & 51.36 & 50.20 & 50.44 & 49.52 & 49.72 & 51.08 & 50.24 & 51.36 & 50.64 & 0.25 \\
\hline Daily feed intake (g/bird) & 79.47 & 76.93 & 77.84 & 77.73 & 77.69 & 78.23 & 76.84 & 79.26 & 78.54 & 0.27 \\
\hline FCR & 1.55 & 1.54 & 1.54 & 1.57 & 1.56 & 1.53 & 1.53 & 1.55 & 1.55 & 0.01 \\
\hline \multicolumn{11}{|l|}{ Finisher (20 days) } \\
\hline ADG (g/bird) & $70.49^{\mathrm{a}}$ & $63.23^{\mathrm{b}}$ & $57.12^{\mathrm{c}}$ & $64.15^{\mathrm{b}}$ & $56.07^{\mathrm{cd}}$ & $62.89^{\mathrm{b}}$ & $52.26^{\mathrm{d}}$ & $65.73^{\mathrm{b}}$ & $55.20^{\mathrm{cd}}$ & 0.51 \\
\hline Daily feed intake (g/bird) & 154.71 & 151.79 & 148.87 & 145.34 & 141.56 & 153.58 & 145.59 & 145.05 & 141.18 & 1.27 \\
\hline FCR & $2.20^{\mathrm{c}}$ & $2.40^{\mathrm{bc}}$ & $2.61^{\mathrm{ab}}$ & $2.27^{\mathrm{bc}}$ & $2.53^{\mathrm{abc}}$ & $2.47^{\mathrm{bc}}$ & $2.83^{\mathrm{a}}$ & $2.21^{\mathrm{c}}$ & $2.56^{\mathrm{ab}}$ & 0.04 \\
\hline \multicolumn{11}{|l|}{ Overall } \\
\hline ADG (g/bird) & $63.98^{\mathrm{a}}$ & $58.38^{\mathrm{b}}$ & $54.44^{\mathrm{c}}$ & $59.17^{\mathrm{b}}$ & $53.91^{\mathrm{c}}$ & $58.73^{\mathrm{b}}$ & $51.76^{\mathrm{c}}$ & $60.83^{\mathrm{ab}}$ & $53.64^{\mathrm{c}}$ & 0.39 \\
\hline Daily feed intake (g/bird) & $129.12^{\mathrm{a}}$ & $123.33^{\mathrm{bc}}$ & $121.51^{\mathrm{bc}}$ & $122.35^{\mathrm{bc}}$ & $119.83^{\mathrm{c}}$ & $124.70^{\mathrm{b}}$ & $119.47^{\mathrm{c}}$ & $122.67^{\mathrm{bc}}$ & $119.84^{\mathrm{c}}$ & 0.41 \\
\hline FCR & $2.02^{\mathrm{d}}$ & $2.14^{\mathrm{bcd}}$ & $2.26^{\mathrm{ab}}$ & $2.07^{\mathrm{cd}}$ & $2.22^{\mathrm{abc}}$ & $2.17^{\mathrm{bcd}}$ & $2.36^{\mathrm{a}}$ & $2.02^{\mathrm{d}}$ & $2.24^{\mathrm{abc}}$ & 0.02 \\
\hline Initial weight (g/bird) & 215.2 & 222.0 & 217.2 & 217.2 & 210.0 & 215.2 & 208.0 & 218.4 & 213.2 & 1.50 \\
\hline Final weight (g/bird) & $2096.4^{\mathrm{a}}$ & $1986.2^{\mathrm{ab}}$ & $1866.4^{\mathrm{cd}}$ & $1956.8^{\mathrm{bc}}$ & $1794.8^{\mathrm{d}}$ & $1980.9^{b}$ & $1760.9^{d}$ & $2007.2^{\mathrm{ab}}$ & $1789.6^{\mathrm{d}}$ & 12.34 \\
\hline Mortality (\%) & 0.0 & 4.0 & 4.0 & 0.0 & 0.0 & 4.0 & 4.0 & 0.0 & 0.0 & 0.89 \\
\hline
\end{tabular}

$\overline{a, b, c}$ Values on the same row with different superscripts differ significantly $(\mathrm{p}<0.05)$.

T1: Corn-soybean meal (SBM) diet without PKE (control), T2: 5\% raw PKE in grower+20\% raw PKE in finisher, T3: 5\% raw PKE in grower+30\% raw PKE in finisher, T4: 5\% enzyme treated PKE in grower+20\% enzyme treated PKE in finisher, T5: 5\% enzyme treated PKE in grower+30\% enzyme treated PKE in finisher, T6: 0\% raw PKE in grower+20\% raw PKE in finisher, T7: 0\% raw PKE in grower+30\% raw PKE in finisher, T8: 0\% enzyme treated PKE in grower+20\% enzyme treated PKE in finisher, T9: 0\% enzyme treated PKE in grower+30\% enzyme treated PKE in finisher.

improving the efficiency of PKE utilization in poultry were based on supplementing different exogenous enzymes into diets containing various levels of PKE. Available data seem to indicate an inconsistency in the results among studies. For example, Chong et al. (2003) reported that FI, ADG and FCR of chickens fed 20\% PKE inclusion diet supplemented with enzyme were not significantly different with those of the PKE-free control diet but higher than diet with similar PKE inclusion rate without enzyme. Similarly, Esuga et al. (2008) showed that broiler chickens fed with 10 and $20 \%$ PKM (palm kernel meal) supplemented with enzyme had higher final weight and ADG than the birds in the control diet (maize based diets) and PKM without enzyme. On the other hand, Omojola and Adesehinwa (2007) and Soltan (2009) found supplementation of enzyme did not improve FI and animal performance in PKE inclusion diets compared to no enzyme PKE diet in broiler chickens. The inconsistent results among studies, as highlighted earlier, could be due to differences in the enzymes used and/or efficacy of the supplemented enzyme in the GIT of the birds (see Introduction). We do not know of any published data on the use of exogenous enzymes to pre-treat the PKE before feeding to chickens, as in the case of this study, except for a recent study (Lawal et al., 2010) which reported higher FI, weigh gain and nutrients digestibility in chickens fed PKE pre-treated with microbial enzyme extract than those fed PKE supplemented with the similar enzyme in the diets. However, the inclusion rate of PKE in their study was only $10 \%$ in the finisher diet which was much lower than the 20 and $30 \%$ inclusion rates used in our study. Although results among studies appeared to be inconsistent, available data seem to agree that PKE (with or without enzyme supplementation) could be included up to about $20 \%$ in broiler diet without significantly affecting growth and feed conversion efficiency of the birds.

\section{Villus height and digesta viscosity}

Intestinal villi are the major site for nutrients absorption, thus higher villus height increases nutrients absorption due to enlarged surface area of the epithelium (Caspary, 1992), while crypt can be regarded as the villus factory and a large crypt indicates rapid tissue turnover (cell renewal) and high demand for new tissues (Yason et al., 1987). Reports on the effects on feeding PKE diets on intestinal villus height and crypt depth were inconsistent. Mustafa et al. (2002) reported that height and width of jejunum and ileum villus in ducks fed PKE inclusion diets were not significantly different. However, Rahim et al. (2007) reported that intestine villus height of broilers decreased with increasing levels of fermented PKE $(0,9,18,27$ and 36\%) in the diets while Zulkifli et al. (2009) found broiler chickens fed $25 \%$ PKM inclusion diet had higher and wider villus which the authors speculated that the higher fiber content of PKM could have stimulated development of the mucosa epithelial cells. Other researchers (Sklan et al., 2003; Jankowski et al., 2011) found that high $\mathrm{CF}$ content in the diet decreased villus height which possibly led to reduced feed intake.

Our results showed no differences $(p>0.05)$ in the intestinal (duodenum, jejunum and ileum) villus height of chickens among treatments (Table 3 ) while differences were detected $(\mathrm{p}<0.05)$ among treatments for duodenum crypt depth but not those of the jejunum and ileum. The 
Table 4. Villus height, crypt depth in small intestine and digesta viscosity of chicken fed with different dietary combination treatments

\begin{tabular}{|c|c|c|c|c|c|c|c|c|c|c|}
\hline Parameter & $\mathrm{T} 1$ & $\mathrm{~T} 2$ & $\mathrm{~T} 3$ & $\mathrm{~T} 4$ & $\mathrm{~T} 5$ & T6 & $\mathrm{T} 7$ & $\mathrm{~T} 8$ & T9 & SEM \\
\hline \multicolumn{11}{|l|}{ Villus height $(\mu \mathrm{m})$} \\
\hline Duodenum & $1,199.20$ & $1,076.20$ & $1,059.40$ & $1,205.40$ & $1,257.90$ & $1,123.80$ & $1,028.60$ & $1,204.20$ & $1,234.30$ & 2.75 \\
\hline Jejunum & 898.81 & 919.14 & 920.39 & $1,111.06$ & $1,025.75$ & 965.91 & 1043.39 & $1,053.80$ & 943.82 & 2.11 \\
\hline Ileum & 797.10 & 865.30 & 766.90 & 904.30 & 954.20 & 821.90 & 882.90 & 847.70 & 815.20 & 2.32 \\
\hline \multicolumn{11}{|l|}{ Crypt depth $(\mu \mathrm{m})$} \\
\hline Duodenum & $155.21^{\mathrm{ab}}$ & $130.24^{\mathrm{bc}}$ & $147.58^{\mathrm{abc}}$ & $134.31^{\mathrm{bc}}$ & $134.71^{\mathrm{bc}}$ & $142.25^{\mathrm{abc}}$ & $123.97^{\mathrm{c}}$ & $142.08^{\mathrm{abc}}$ & $166.69^{\mathrm{a}}$ & 0.25 \\
\hline Jejunum & 136.85 & 122.99 & 137.68 & 151.61 & 129.51 & 139.82 & 135.18 & 149.12 & 136.96 & 0.33 \\
\hline Ileum & 106.18 & 140.00 & 134.36 & 120.58 & 134.01 & 120.00 & 135.77 & 140.88 & 113.29 & 0.37 \\
\hline Digesta viscosity $(\mathrm{Pa} \cdot \mathrm{s})$ & 0.35 & 1.78 & 0.50 & 1.34 & 0.56 & 0.16 & 1.15 & 0.56 & 1.11 & 0.01 \\
\hline
\end{tabular}

$\overline{a, b, c}$ Values on the same row with different superscripts differ significantly $(\mathrm{p}<0.05)$.

T1: Corn-soybean meal (SBM) diet without PKE (control), T2: 5\% raw PKE in grower +20\% raw PKE in finisher, T3: $5 \%$ raw PKE in grower $+30 \%$ raw PKE in finisher, T4: 5\% enzyme treated PKE in grower $+20 \%$ enzyme treated PKE in finisher, T5: 5\% enzyme treated PKE in grower $+30 \%$ enzyme treated PKE in finisher, T6: 0\% raw PKE in grower $+20 \%$ raw PKE in finisher, T7: 0\% raw PKE in grower $+30 \%$ raw PKE in finisher, T8: 0\% enzyme treated PKE in grower $+20 \%$ enzyme treated PKE in finisher, T9: 0\% enzyme treated PKE in grower $+30 \%$ enzyme treated PKE in finisher.

duodenum crypt depth of birds fed with $30 \%$ enzyme treated PKE (T9) and control (T1) were significantly higher $(\mathrm{p}<0.05)$ than all other PKE diets. However, comparison using orthogonal contrast analysis showed that villus height of duodenum and jejunum of bird fed with enzyme treated PKE was significantly higher $(\mathrm{p}<0.05)$ than those in raw PKE. The mean values were $1,246.1$ vs $1,044.0 \mu \mathrm{m}$ for duodenum and $1,082.4$ vs $942.5 \mu \mathrm{m}$ for jejunum, respectively, for enzyme treated and raw PKE diets. In addition, mean ileum crypt depth of all birds fed with PKE was also higher $(\mathrm{p}<0.05)$ than those of the PKE free control diet (129.9 vs $106.2 \mu \mathrm{m}$, respectively). The ratio of crypt depth to villus height in treatment diets was not different in each section of small intestine. Our results, in general, seem to suggest an increase in intestinal villus height and crypt depth in birds fed enzyme treated PKE. Since fiber content of the enzyme treated PKE was significantly reduced compared to the untreated one, our result thus not supporting the earlier speculation that higher villus height and/or crypt depth could be stimulated by the high fiber content in PKE diets. However, we do not have any reasons to explain for the effects.

Intestinal digesta viscosity is an indicator of nutrient digestibility and absorbability. Galactomannan and mannan are anti-nutritional factors present in feedstuffs including PKE and these compounds were reported to decrease nutrient digestibility and absorbability due to increased digesta viscosity of the gut content (Sundu and Dingle, 2003). The primary objective of the present study was to use enzyme to break down the insoluble non-starch polysaccharides of PKE into smaller molecule polymers which can then be made available to the chickens. Since 58 to $78 \%$ of the PKE fiber is insoluble glucomannan (Daud and Jarvis, 1992; Dusterhoft et al., 1992; Sundu and Dingle, 2003), large proportion of the end-products of enzymatic hydrolysis of its fiber would be galactomannan and mannan.
Digesta viscosity recorded in this study ranged from 0.35 to $1.78 \mathrm{~Pa} \cdot \mathrm{s}$, but no significant differences $(\mathrm{p}>0.05)$ were detected among treatments (Table 4). Our result is in agreement with that of Sundu and Dingle (2003) who reported that galactomannan of PKE which is hard, highly crystalline and with high mannose: galactose ratio and thus low water absorption capacity may not significantly increase its viscosity. Bedford and Schulze (1998) also reported that digesta viscosity had no effect on growth of chicken when this value is lower than $10 \mathrm{mPa} \cdot \mathrm{s}$. However, several studies reported enzyme supplementation decrease intestinal digesta viscosity in soybean meal (Saleh et al., 2003) and wheat-based (Gunal et al., 2004) diets in chickens. The discrepancy between the above two studies and those of Sundu and Dingle (2003) and the present study could be due to the feed ingredients used and thus their endproducts from enzymatic hydrolysis.

\section{CONCLUSIONS}

Enzyme treatment effectively hydrolyzed the fiber components (cellulose and hemicelluloses) of PKE resulted in $38 \%$ increase in the TME value of the enzyme treated PKE compared to the raw PKE. As to why improvements in both reductions of fiber contents and TME of enzyme treated PKE were not reflected in the ADG and FCR of chickens fed enzyme treated PKE deserve further elucidations. However, we would like to offer the following explanation: because the fiber in PKE is mainly in the form of hemicelluloses-mannan (Daud and Jarvis, 1992; Dusterhoft et al., 1992; Sundu and Dingle, 2003) and thus large proportion of the sugars released during enzymatic treatment comprised of mannose. It has been reported that the absorption of mannose is much lower than glucose (Wilson and Vincent, 1955), particularly when glucose is present in the system. Therefore, although enzymatic 
treatment of PKE released large amount of sugars, they are primarily mannose which are poorly absorbed and thus of little use to the chickens. Our results, in agreement with several previous studies, suggested that PKE can be included up $20 \%$ in broiler diets without adversely affecting growth and feed conversion efficiency.

\section{ACKNOWLEDGEMENTS}

This study was supported by Technofund of the Ministry of Agro-industry Malaysia. The authors would also like to thank FTR Bio-Agro Sdn. Bhd for providing the enzyme for this study.

\section{REFERENCES}

Alimon, A. R. 2004. The nutritive value of palm kernel cake for animal feed. Palm Oil Dev. 40:12-14.

AOAC. 1990. Official Method of Analysis. Association of Official Analytical Chemists, Washington, DC. USA.

Bedford, M. R. and H. Schulze. 1998. Exogenous enzymes for pigs and poultry. Nutr. Res. Rev. 11:91-114.

Bejo, M. H. 1990. Gastrointestinal response to copper excess: studies on copper (and zinc) loader rats. PhD Thesis, University of Liverpool, UK.

Bilgili, S. F., G. H. Arscott, M. P. Goeger, J. A. Harper and H. S. Nakaue. 1982. True ME values of some poultry feedstuffs available in the Pacific Nortwest. Agricultural experiment station special report 657, Oregon State University, Corvallis, USA.

Caspary, W. F. 1992. Physiology and pathophysiology of intestinal absorption. Am. J. Clin. Nutr. 55:299S-308S.

Chong, C. H., R. Blair, I. Zulkifli and Z. A. Jelan. 1998. Physical and chemical characteristics of Malaysian palm kernel cake (PKC). In: Proceeding of $20^{\text {th }}$ MSAP Conference, Penang, Malaysia, pp. 62-63.

Chong, C. H., I. Zulkifli, R. Blair and Z. A. Jelan. 2003. Effects of dietary inclusion of palm kernel cake and enzyme supplementation on performance and metabolisable energy in broiler chickens. Malaysian J. Anim. Sci. 8:59-70.

Daud, M. J. and M. C. Jarvis. 1992. Mannans of oil palm kernels. Phytochem. 31:463-464.

Dusterhoft, E. M., M. A. Posthumus and A. G. J. Voragen. 1991. Non-strach polysaccharides from sunflower (helianthus annus) meal and palm kernel (Elaeis guineenis) meal preparation of cell well material and extraction of polysaccharide fractions. J. Sci. Food Agric. 55:411-422.

Esuga, P. M., A. A. Sekoni, J. J. Omage and G. S. Bawa. 2008. Evaluation of enzyme (Maxigrain ${ }^{\circledR}$ ) supplementation of graded levels of palm kernel meal (PKM) on the performance of broiler chickens. Pakistan J. Nutr. 7:607-613.

Goering, H. K. and P. J. Van Soest. 1970. Forage fiber analysis (Apparatus, Reagent, Procedures and some Application). In Agricultural Handbook. No. 397, ARS, USDA, Washington, DC. USA.

Gunal, M., S. Yasar and J. M. Forbes. 2004. Performance and some digesta parameters of broiler chicken given low or high viscosity wheat-base diets with or without enzyme supplementation. Turk. J. Vet. Anim. Sci. 28:323-327.

Iyayi, E. A. and B. I. Davies. 2005. Effect of enzyme supplementation of palm kernel meal and Brewer's dried grain on the performance of broilers. Int. J. Poult. Sci. 4:76-80.

Jankowski, J., A. Lecewicz, Z. Zdunczyk, J. Juskiewicz and B. A. Slominski. 2011. The effect of partial replacement of soybean meal with sunflower meal on ileal adaptation, nutrient utilisation and growth performance of young turkeys. Br. Poult. Sci. 52:456-465.

Knudsen, K. E. B. 1997. Carbohydrate and lignin contents of plant material used in animal feeding. Anim. Feed Sci. Technol. 67:319-338.

Lawal, T. E., E. A. Iyayi, B. A. Adeniyi and O. A. Adaramoye. 2010. Biodegradation of palm kernel cake with multienzyme complexes from fungi and its feeding value for broilers. Int. J. Poult. Sci. 9:695-701.

McNab, J. M. and J. C. Blair. 1988. Modified assay for true and apparent metabolizable energy based on tube feeding. Br. Poult. Sci. 29:697-707.

Muangkeow, N. and C. Chinajariyawong. 2009. Determination of true amino acid digestibility and metabolizable energy in fermented palm kernel meal with Aspergillus wentii TISTR 3075 for chickens. Walailak J. Sci. Technol. 6:231-241.

Mustafa, M. F., A. R. Alimon and M. Hair-Bejo. 2002. The effect of feeding palm kernel cake on the morphology of the gastrointestinal tract of Muscovy ducks. In: Proceeding of $24^{\text {th }}$ MSAP Annual Conference, Penang, Malaysia, pp. 41-42.

Nadeem, M. A., A. H. Gilani, A. G. Khan and M. U. Nisa. 2005. True metabolizable energy value of poultry feedstuffs in Pakistan. Int. J. Agric. Biol. 7:990-994.

NRC. 1994. Nutrient requirements of poultry. National academy press, Washington, DC. USA.

Omojola, A. B. and A. O. K. Adesehinwa. 2007. Performance and carcass characteristics of broiler chickens fed diets supplemented with grade levels of Roxazyme G. Int. J. Poult. Sci. 6:335-339.

Pardo, A. G. and F. Forchiassin. 1999. Influence of temperature and $\mathrm{pH}$ on cellulase activity and stability in Nectria catalinensis. Rev. Argent. Microbiol. 31:31-35.

Rahim, F., Sabrina, Rusmawati and M. Syibli. 2007. Broiler small intestine villi response to feed containing palm kernel cake which fermented with Rhizopus sp. J. Indon. Trop. Anim. Agric. 32:251-256.

Saenphoom, P., J. B. Liang, Y. W. Ho, T. C. Loh and M. Rosfarizan. 2011. Effect of enzyme treatment on chemical composition and production of reducing sugars in palm (Elaeis guineenis) kernel expeller. Afr. J. Biotechnol. 10:15372-15377.

Saleh, F., A. Ohtsuka, T. Tanaka and K. Hayashi. 2003. Effect of enzyme of microbial origin on in vitro digestibilities of dry matter and crude protein in soybean meal. Anim. Sci. J. 74:2329.

SAS. 1998. User's guide : Statistics, Version 9.2 Edition. SAS. Inst. Cary, NC, USA.

Sekoni, A. A., J. J. Omage, G. S. Bawa and P. M. Esuga. 2008. Evaluation of enzyme (Maxigrain ${ }^{\circledR}$ ) treatment of graded levels of palm kernel meal (PKM) on nutrient retention. Pakistan J. Nutr. 7:614-619.

Sibbald, I. R. 1975. Indirect methods for measuring metabolizable 
energy in poultry feeds and ingredients. Feedstuffs 47:22-24.

Sibbald, I. R. 1989. Metabolizable energy evaluation of poultry dites. In Recent Developments in Poultry Nutrition (Ed. D. J. A. Cole and W. Haresign), pp. 12-26. UK. Butterworth, Essex.

Siti Norita, M., M. Rosfarizan and A. B. Ariff. 2010. Evaluation of the activities of concentrated crude mannan-degrading enzymes produced by Aspergillus niger. Malaysian J. Microbiol. 6:171-180.

Sklan, D., A. Smirnov and I. Plavnik. 2003. The effect of dietary fibre on the small intestines and apparent digestion in the turkey. Br. Poult. Sci. 44:735-740.

Soltan, M. A. 2009. Growth performance, immune response and carcass traits of broiler chicks fed on graded level of palm kernel cake without or with enzyme supplementation. Livest. Res. Rural Dev. 21.

Steel, R. G. D. and J. H. Torrie. 1980. Principles and procedures of statistic a biomatereal approach. ( $2^{\text {nd }}$ ed), McGrow-Hill, New York, USA.

Sundu, B. and J. Dingle. 2003. Use of enzymes to improve the nutritional value of palm kernel meal and copra meal. Queensland Poult. Sci. Symp. 11:1-15.

Sundu, B., A. Kumar and J. Dingle. 2006. Palm kernel meal in broiler diets: Effect on chicken performance and health. World's Poult. Sci. J. 62:316-325.
Tessier, M., D. Du Tremblay, C. Klopfenstein, G. Beauchamp and M. Boulianne. 2003. Abdominal skin temperature variation in healthy broiler chickens as determined by thermography. Poult. Sci. 82:846-849.

Wilson, T. H. and T. N. Vincent. 1955. Absorption of sugars in vitro by the intestine of the golden hamster. J. Biol. Chem. 216:851-866.

Yahya, M., K. Azhar, F. Y. Chin, A. B. Idris and N. Vincent. 2000. Use of commercial enzyme to improve utilization of palm kernel expeller meal in poultry diets. Proceeding of $22^{\text {nd }}$ MSAP Annual Conference, Kota Kinabalu, Malaysia, pp. 155156.

Yason, C. V., B. A. Summers and K. A. Schat. 1987. Pathogenesis of rotavirus infection in various age groups of chickens and turkeys: Pathology. Am. J. Vet. Res. 48:927-938.

Yeong, S. W., T. K. Mukherjee and R. I. Hutagulung. 1983. The nutritive value of palm kernel cake as a feedstuff for poultry. Proceeding of the national workshop on oil palm by-products utilization, PORIM, Kuala Lumpur, pp. 100-107.

Yokomizo, F. 2004. Mannose-containing palm kernel meal. US Patent 20040151804A1.

Zulkifli, I., H. S. Iman Rahayu, A. R. Alimon, M. K. Vidyadaran and S. A. Babjee. 2009. Gut micoflora and intestinal morphology of commercial broiler chickens and Red Jungle Fowl fed diets containing palm kernel meal. Arch Geflugelk. 73:49-55. 